\title{
Some Suggestions for Controlling Benghal Dayflower in Field Nurseries 1
}

\section{Robert Stamps ${ }^{2}$}

Benghal dayflower (Commelina benghalensis L.), an increasingly problematic weed, is also known as jio, tropical spiderwort, hairy wandering jew, and Indian dayflower, among other names. It is an herbaceous monocot (flowering plant that produces one seed leaf and has fibrous roots, leaves with parallel veins and flower parts occurring in multiples of three) that is native to Asia and tropical Africa. It was first collected in the continental United States in 1928 and in 1983 was designated a "noxious weed" by the U.S. Department of Agriculture. Benghal dayflower has many characteristics that make it a successful weed in field nurseries.

First is its tolerance to glyphosate (Glyfos ${ }^{\circledR}$ Pro, Roundup Pro $^{\circledR}$, Touchdown ${ }^{\circledR}$, etc.). Widespread use of this herbicide has greatly reduced competition from other, non-glyphosate-resistant plants that might have suppressed Benghal dayflower establishment and growth in the past. In addition, some nursery growers have depended on glyphosate as their sole herbicide to control weeds. Glyphosate, besides having limited effectiveness against Benghal dayflower, has no residual activity to control Benghal dayflower seed germination. Therefore, if a preemergence herbicide with residual activity is not also used, Benghal dayflower plants will reestablish from seed even if glyphosate or other postemergence herbicides without residual activity actually kill existing plants.

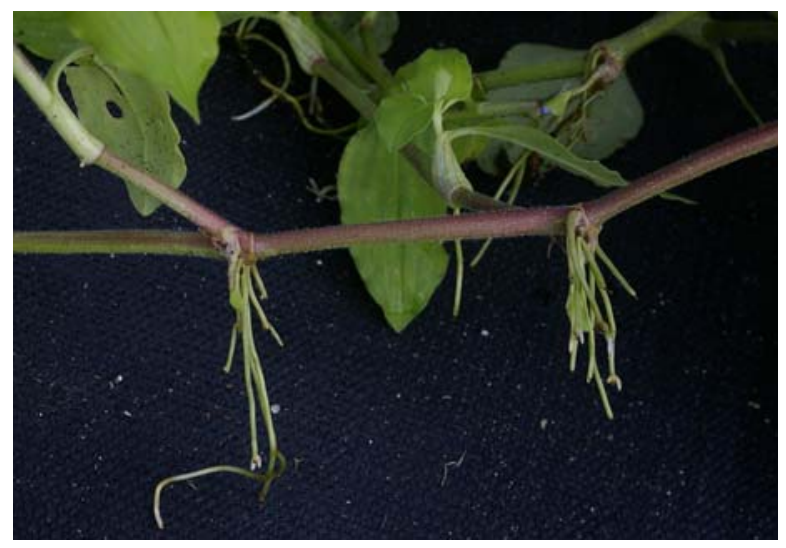

Figure 1. Benghal dayflower readily roots from nodes along its stems. Credits: R. Stamps

Second, Benghal dayflower is a vigorous plant with succulent stems that can root at each node (Figure 1). This allows the plants to spread vegetatively. Stem pieces buried below the soil surface have been shown to become established and produce new plants. This characteristic also makes Benghal dayflower stems hard to weed.

1. This document is ENH1085, one of a series of the Environmental Horticulture Department, Florida Cooperative Extension Service, Institute of Food and Agricultural Sciences, University of Florida. Original publication date January, 2008. Visit the EDIS Web Site at http://edis.ifas.ufl.edu.

2. Robert H. Stamps, Professor of Environmental Horticulture and Extension Cut Foliage Specialist, Mid-Florida Research and Education Center, t2725 South Binion Road, Apopka, Florida

The Institute of Food and Agricultural Sciences (IFAS) is an Equal Opportunity Institution authorized to provide research, educational information and other services only to individuals and institutions that function with non-discrimination with respect to race, creed, color, religion, age, disability, sex, sexual orientation, marital status, national origin, political opinions or affiliations. U.S. Department of Agriculture, Cooperative Extension Service, University of Florida, IFAS, Florida A. \& M. University Cooperative Extension Program, and Boards of County Commissioners Cooperating. Larry Arrington, Dean 
Thirdly, this plant produces flowers both above and below ground. And once established, seed production from these flowers can be as high as 1,100 per square foot.

Fourth, besides producing a lot of seed, Benghal dayflowers produce four different types of seeds that have various germination characteristics (dormancies and optimum germination temperatures) that help new Benghal dayflower plants to become established (Figure 2). Also, some seeds can germinate several inches in the soil and the seedlings can successfully reach the soil surface. By the time they emerge from the soil, these seedlings have formed deep root systems, which makes them resistant to some preemergence herbicides. Larger seeds can grow to the soil surface from greater depths than smaller seeds.

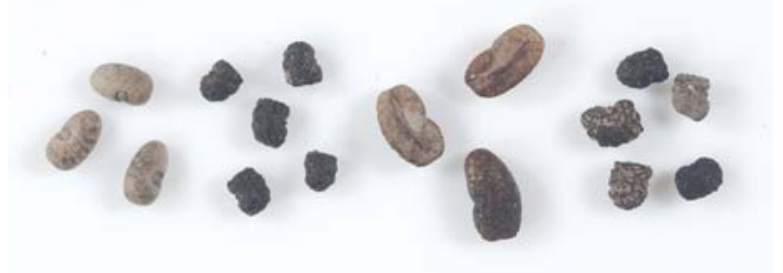

Figure 2. Benghal dayflower seeds from above-ground (left) and subterranean (right) flowers. Credits: R. Stamps

To make matters worse, in addition to being a well-adapted invasive plant, Benghal dayflower is also a host to root-knot nematodes (Meloidogyne incognita), a widespread and economically important nematode pest of ornamental and other crops.

\section{Identification}

Benghal dayflower can generally be differentiated from the other dayflowers that grow in most of Florida:

- By their violet rather than blue flowers (Figure 3)

- By their broader (leaf length to width ratio of less than 3:1), less lance-shaped, 3/4-inch to 3 1/2-inch-long leaves (Figure 4 )

- By the presence of hairs (pubescence) on the upper surfaces and edges (margins) of the leaves
- By the production of whitish, underground (subterranean) flowers (Figure 5)

(Commelina forskaolii also produces subterranean flowers but it has only been reported as occurring at one site in Miami-Dade county.)

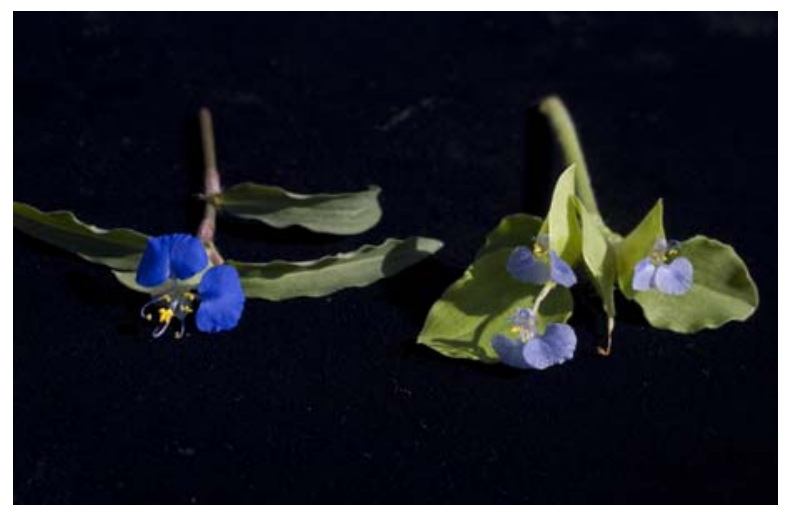

Figure 3. Benghal dayflower (right) has violet/lavender flowers rather than blue ones that are common for many other dayflowers. Credits: R. Stamps

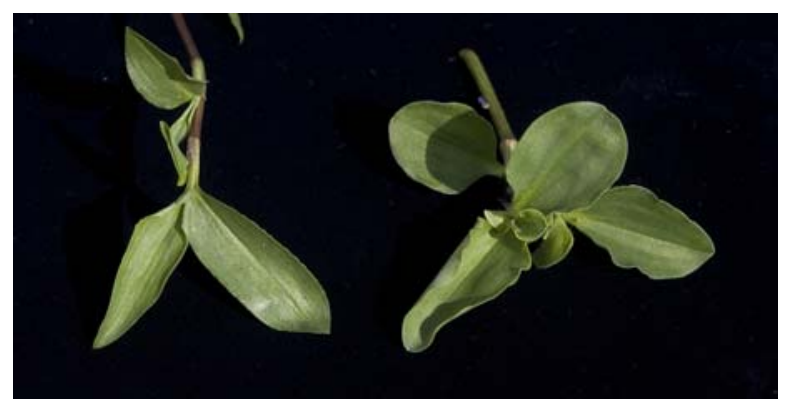

Figure 4. The leaves of Benghal dayflower (right) are generally broader than those of other dayflowers currently in Florida (whitemouth dayflower, C. erecta, on left). Credits: R. Stamps

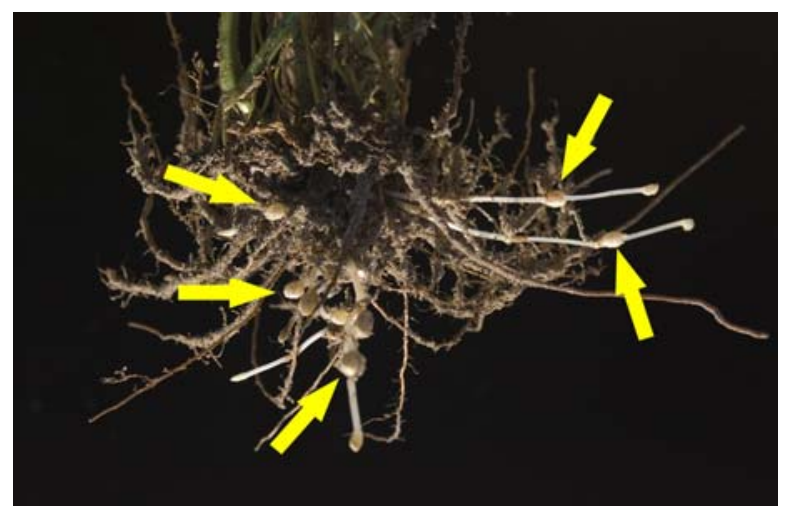

Figure 5. Benghal dayflower is one of the few plants in the world that produces underground (subterranean) flowers (whitish in color). Credits: R. Stamps 


\section{Control}

\section{Exclusion is the Best Control}

The most effective method for controlling Benghal dayflower is to institute procedures to prevent it from being brought into the nursery in the first place. Remember, the cost of preventing weed introductions is usually much lower than the cost of managing weeds once you have an infestation. Efforts should be made to prevent the introduction of this weed on uncleaned equipment, in growing medium, or with incoming plant material. Employees accepting plant material from outside sources should scrutinize the new plants, looking for Benghal dayflower (and other weeds and pests). In addition, if possible, visit your media and plant suppliers to make sure they do not have Benghal dayflower at their operations.

Of course, all your employees should be trained to identify and control Benghal dayflower (or other weeds) they might encounter. It is particularly important to make sure that they know the key characteristics that help differentiate Benghal dayflower from the other dayflowers they are likely to encounter. This is because Benghal dayflower is on both the U.S. Department of Agriculture's Federal and the State of Florida's noxious weed lists. Because of this, the presence of Benghal dayflower in a nursery can lead to quarantine restrictions being imposed and the shipping of plants being prohibited.

\section{Prevention of Establishment and Spread}

Besides the use of procedures to prevent the introduction of Benghal dayflower in the first place, the use of preemergence herbicides with residual activity as an additional line of defense can help prevent Benghal dayflower from successfully invading your nursery. These chemicals can create a protective barrier that can kill germinating weed seeds, thus reducing the seed reservoir and, thereby, potentially decreasing weed pressure. In addition, some of them can inhibit the weeds from rooting into the soil, thereby reducing weed growth and making weeding easier. As with other pesticides, growers should rotate among preemergence herbicides with different modes of action in order to reduce the chances of selection for resistance by Benghal dayflower. Not many of the preemergence herbicides labeled for use on ornamental crops have been evaluated for controlling Benghal dayflower; however, those that have already been tested and shown promise are indicated in Table 1 with a $\$$. Undoubtedly with more testing more materials will be identified that can help control Benghal dayflower from seed. Additional information on preemergence herbicides labeled for use on ornamentals is available at http://edis.ifas.ufl.edu/. Note that preemergence herbicides need to be activated by water (irrigation or rainfall) to form the protective barrier on the soil surface.

\section{Eradication of Existing Infestations}

First, make sure the weeds in question are actually Benghal dayflower (Commelina benghalensis) rather than Asiatic dayflower ( $C$. communis), Carolina dayflower (C. caroliniana), common dayflower ( $C$. diffusa), Virginia dayflower* (C. virginica), whitemouth dayflower* (C. erecta) or some other dayflower $[*=$ Florida native]. See http://www.plantatlas.usf.edu/ for a list of species found in Florida and pictures of some of them. The information provided earlier in this article provides some characteristics useful for identifying Benghal dayflower. Department of Plant Industry inspectors and county extension agents can also help with identification of dayflowers.

There are multiple methods that, used together (integrated pest management [IPM]), can help you rid your nursery of Benghal dayflower. These methods include physical (cultural, mechanical), biological and chemical techniques.

\section{Physical Control Methods}

Mowing. Mowing may be beneficial in row middles when combined with techniques to keep the cover crop vigorous and weed-free. Care should be made to mow at a high enough height that the cover crop still shades the ground even after mowing. Mowing can actually spread Benghal dayflower by chopping up and spreading stem pieces around to where they can then root into the ground and establish new plants. Mowing can also disperse Benghal dayflower seed that can then germinate where they 
Table 1. Site-of-action groups†, common names (active ingredients), trade names and manufacturers/distributors for some preemergence herbicides labeled for ornamental crops. Additional trade-named products and various fertilizer formulations containing some of these herbicides are also available but are not listed in this table. Be aware that not all these products are labeled for use on containerized ornamentals.

\begin{tabular}{|c|c|c|}
\hline $\begin{array}{l}\text { Common name(s)/ } \\
\text { active ingredient(s) }\end{array}$ & Trade name(s) & Manufacturer(s) or distributor(s) \\
\hline GROUP & 2 & HERBICIDE \\
\hline imazaquin & Image ${ }^{\circledR} 70 \mathrm{DG}$ & BASF \\
\hline GROUP & 3 & HERBICIDES \\
\hline DCPA & Dacthal ${ }^{\circledR} 6 \mathrm{~F}, 75 \mathrm{WP}$ & AMVAC \\
\hline dithiopyr & $\begin{array}{l}\text { Dimension }^{(} 1 \mathrm{EC}, 2 \mathrm{EW}, 40 \mathrm{WP} \text {; Dithiopyr } \\
\text { 40WSB; } \text { Lifeguard }^{\circledR} \text { 40WSP }\end{array}$ & $\begin{array}{l}\text { Dow AgroSciences; Quali-Pro; } \\
\text { Lesco }\end{array}$ \\
\hline oryzalin & $\begin{array}{l}\text { Oryzalin 4AS; Oryzalin 1.67G; Oryzalin Pro } \\
\text { 4AS; Surflan }{ }^{\circledR} \text { 1.67G; Surflan }{ }^{\circledR} \text { 4AC Specialty; } \\
\text { Surflan }^{\circledR} \text { 4AS; Surflan }{ }^{\circledR} \text { 85WDG Specialty }\end{array}$ & $\begin{array}{l}\text { FarmSaver.com, Vegetation } \\
\text { Manager; Quali-Pro; Loveland } \\
\text { Products; United Agri Products; } \\
\text { United Phosphorus; Lesco, United } \\
\text { Agri Products; United Phosphorus, } \\
\text { United Agri Products }\end{array}$ \\
\hline pendimethalin & $\begin{array}{l}\text { Corral }^{\mathrm{TM}} 2.68 \mathrm{G} ; \text { Pendulum } \\
{ }^{\circledR} 2 \mathrm{G}, 3.8 \mathrm{AS}, 3.3 \mathrm{EC} ; \\
\text { Pre-M }^{\circledR} \text { 3.3EC, 60DG }\end{array}$ & Scotts; BASF; Lesco \\
\hline prodiamine & $\begin{array}{l}\text { Barricade }^{\circledR} 4 \mathrm{FL}, 65 \mathrm{WG} \text {; Cavalcade }{ }^{\mathrm{TM}} 65 \mathrm{WDG} ; \\
\text { Endurance }^{\circledR} 65 \mathrm{WDG} \text {, ProClipse }{ }^{\mathrm{TM}} \text {; ProdiaGuard } \\
\text { 65WDG; Prodiamine } 65 \text { WDG; RegalKade }{ }^{\circledR} \\
\text { 0.5G, 65WDG; Stonewall }{ }^{\circledR} 65 \mathrm{WDG} \text {; etc. }\end{array}$ & $\begin{array}{l}\text { Syngenta; Sipcam Agro USA; } \\
\text { Nufarm Turf \& Specialty; Control } \\
\text { Solutions; FarmSaver.com; Regal } \\
\text { Chemical; Lesco; etc. }\end{array}$ \\
\hline trifluralin & Treflan $^{\mathrm{TM}} 5 \mathrm{G}$; Trifluralin 10G & $\begin{array}{l}\text { Lebanon Seaboard, United Agri } \\
\text { Products, Loveland }\end{array}$ \\
\hline benefin + oryzalin & $\mathrm{XL}^{\circledR} 2 \mathrm{G}$ & Helena Chemical \\
\hline GROUP & 5 & HERBICIDE \\
\hline simazine & $\begin{array}{l}\text { Princep }{ }^{\circledR} 4 \mathrm{~L}, ; \text { Simazine } 4 \mathrm{~L} \text {, Simazine 90DF, } \\
\text { 90WDG; Sim-Trol }{ }^{\circledR} 4 \mathrm{~L}, 90 \mathrm{DF}\end{array}$ & $\begin{array}{l}\text { Syngenta; Drexel, Riverside, UAP; } \\
\text { Sipcam Agro USA }\end{array}$ \\
\hline GROUP & 8 & HERBICIDES \\
\hline bensulide & $\begin{array}{l}\text { Bensumec }{ }^{\mathrm{TM}} 4 \mathrm{LF} ; \text { Prefar }^{\circledR} 4 \mathrm{E} ; \text { Pre-San }^{\circledR} 7 \mathrm{G}, \\
12.5 \mathrm{G}\end{array}$ & PBI/Gordon; Gowan; PBI/Gordon \\
\hline EPTC & Eptam $^{\circledR} 7 \mathrm{E}$ & Gowan \\
\hline GROUP & 12 & HERBICIDE \\
\hline norflurazon & Predict $^{(} 78.6$ WDG & Nufarm Turf \& Specialty \\
\hline GROUP & 14 & HERBICIDES \\
\hline flumioxazin & BroadStar $^{\mathrm{TM}} 0.25 \mathrm{G}$, SureGuard ${ }^{\mathrm{TM}}$ 51WDG & Valent USA \\
\hline oxadiazon & Ronstar $^{\circledR}$ 2G, Ronstar ${ }^{\circledR}$ 50WSP & Bayer CropScience, Regal \\
\hline oxyfluorfen & $\begin{array}{l}\text { Galigan }^{\circledR} \text { 2EC; Goal }{ }^{\circledR} 1.6 \mathrm{E}, 2 \mathrm{EC} \text {; Granular } \\
\text { Herbicide } 63 \text { 2G; OxiFlo 2EC }\end{array}$ & $\begin{array}{l}\text { Makhteshim Agan; Dow } \\
\text { AgroSciences; Harrell's; } \\
\text { FarmSaver.com }\end{array}$ \\
\hline oxyfluorfen + oxadiazon & Lasar $^{\mathrm{TM}}$ 3G; OO-Herbicide ${ }^{\mathrm{TM}} 3 \mathrm{G}$ & $\begin{array}{l}\text { United Agri Products; Regal } \\
\text { Chemical }\end{array}$ \\
\hline GROUP & 15 & HERBICIDES \\
\hline napropamide & Devrinol $^{\circledR} 50 \mathrm{DF}$, Devrinol ${ }^{\circledR} 2 \mathrm{G}$ & United Phosphorus \\
\hline pronamide & $\operatorname{Kerb}^{\circledR} 50 \mathrm{WP}$ & Dow AgroSciences \\
\hline S-metolachlor & Pennant Magnum ${ }^{\otimes} 7.6 \mathrm{EC}$ & Syngenta \\
\hline GROUP & 21 & HERBICIDE \\
\hline isoxaben & Gallery $^{\mathrm{TM}} 75 \mathrm{DF}$ & Dow AgroSciences \\
\hline
\end{tabular}


Table 1. Site-of-action groups†, common names (active ingredients), trade names and manufacturers/distributors for some preemergence herbicides labeled for ornamental crops. Additional trade-named products and various fertilizer formulations containing some of these herbicides are also available but are not listed in this table. Be aware that not all these products are labeled for use on containerized ornamentals.

\begin{tabular}{|c|c|c|}
\hline $\begin{array}{l}\text { Common name(s)/ } \\
\text { active ingredient(s) }\end{array}$ & Trade name(s) & Manufacturer(s) or distributor(s) \\
\hline \multicolumn{3}{|c|}{$\begin{array}{l}\text { Combination products with more than one site of action } \\
\text { [site-of-action group number in brackets] }\end{array}$} \\
\hline $\begin{array}{l}\text { napropamide [15] + } \\
\text { oxadiazon [14] }\end{array}$ & PrePair $^{\circledR} 6 G$ & United Agri Products \\
\hline $\begin{array}{l}\text { oxadiazon [14] + prodiamine } \\
\text { [3] }\end{array}$ & RegalStar $^{\circledR} \mathrm{G} \& \mathrm{II}, 1.2 \mathrm{G}$ & Regal Chemical \\
\hline oxyfluorfen [14] + oryzalin [3] & Double O E-Pro 3G, Rout $^{\circledR} 3 G$ & Etigra, Scotts \\
\hline $\begin{array}{l}\text { oxyfluorfen [14] + } \\
\text { pendimethalin [3] }\end{array}$ & $\mathrm{OH} 2^{\circledR} 3 \mathrm{G}$ & Scotts \\
\hline oxyfluorfen [14] + trifluralin [3] & Granular Herbicide 75 5G & Harrell's \\
\hline trifluralin [3] + isoxaben [21] & Preen $^{\circledR}$ Plus 1.875G; Snapshot ${ }^{\circledR}$ 2.5TG & $\begin{array}{l}\text { Lebanon Seaboard; Dow } \\
\text { AgroSciences }\end{array}$ \\
\hline $\begin{array}{l}\text { trifluralin [3] + isoxaben [21] + } \\
\text { oxyfluorfen [14] }\end{array}$ & Showcase ${ }^{\mathrm{TM}} 2.5 \mathrm{G}$ & Dow AgroSciences \\
\hline
\end{tabular}

† Herbicide groups are based according to primary sites of action (Weed Technology 11:384-393, [1997]) and can be used to select herbicides that have differing sites of action. This information can be used to help select herbicides so as to minimize the potential for the development of herbicide-resistant weeds. $2=$ ALS/AHAS inhibitors, $3=$ microtubule assembly inhibitors, 5 = photosystem II inhibitors, 8 = lipid synthesis inhibitors, 12 = carotenoid biosynthesis inhibitors, 14 = PPO inhibitors, $15=$ acetamides (unknown site of action), $20=$ cellulose synthase inhibitors, $21=$ inhibition of cell wall synthesis site $B$.

$\ddagger$ Based on research trials, this active ingredient has activity against Benghal dayflower germinating from seed.

Combination products containing these active ingredients may also be effective. Research is underway to determine what other herbicides on this list will also help control Benghal dayflower.

land, again establishing new plants. In addition, both plant parts and seed may get moved from one area to another on the mowing equipment itself.

Mulches. The use of mulches, both organic and inorganic, can help prevent the establishment and spread of Benghal dayflower. Organic mulches should be applied about 2 to 3 inches deep and should be kept 3 inches away from the trunks of crop plants. Their use around the perimeter and in areas devoid of competitive cover crops of the nursery can inhibit the introduction and spread of Benghal dayflower.

Hoeing and hand-weeding. Although onerous, use hoeing and hand-weeding to eradicate small infestations. Whole plants, including roots and underground flowers, should be hoed/pulled and immediately bagged and disposed of. It is easier to pull the plants if the soil is moist and the plants are small. Do not leave Benghal dayflower stem pieces in the nursery; they will root and establish new plants. Also, measures should be taken to prevent Benghal dayflower from reestablishing from seed in the hoed/weeded areas.

\section{Biological Control Methods}

Plant competition can be an effective weed control technique. Maintaining weed-free cover crops in the middles between the rows and around the perimeter of the nursery can help prevent Benghal dayflower plants from getting close enough to infest the crops. However, cover crops (just like weeds) can compete with nursery crops so they must be managed so that there are vegetation-free zones around the nursery plants. Bahiagrass is a common cover crop grown in row middles. It should be mowed to a height of about $31 / 2$ to 4 inches, and, ideally, 
frequently enough that only about of the leaf blade is removed at each mowing. This will help ensure that it grows vigorously, maintains a canopy over the soil and remains competitive with broadleaf weeds.

\section{Chemical Control Methods}

Postemergence herbicides (Table 2), combined with preemergence herbicides (Table 1), can aid greatly in the eradication of Benghal dayflower. Postemergence herbicides can be classified as contact (damage is limited to only the Benghal dayflower stem and leaf areas that are in direct contact with the herbicide) or systemic (the herbicide moves from the sites of contact to other parts of the plant). The systemic materials, in general, are more effective in killing perennial weeds like Benghal dayflower. Keep in mind, however, that Benghal dayflower is tolerant to glyphosate, a popular systemic herbicide.

\section{Some Factors Affecting the Efficacy of Postemergence Herbicides:}

Soil moisture - Research has shown that damage to Benghal dayflower from some herbicides (for example, flumioxazin, glufosinate, metolachor) increases with increasing soil moisture conditions. The effects of several other herbicides were not affected by soil moisture.

Benghal dayflower growth - The smaller the plant and the more vigorously it is growing, the better the chances of killing it.

Application rate-Read the product label completely and follow all guidelines. Have a knowledgeable person check your calculations to make sure the correct amount of herbicide is used for each tank size.

Water quality - There are adjuvants that can help reduce the detrimental effects of hard water on herbicide effectiveness. For example, hard water ions $\left(\mathrm{Ca}^{2+}, \mathrm{Fe}^{3+}, \mathrm{Mg}^{2+}\right)$ can bind with salts of certain herbicides and surfactants to form insoluble salts, thereby reducing their efficacy. Glufosinate and glyphosate are two salt-formulated herbicides commonly used in nurseries. Ammonium sulfate $\left(\mathrm{NH}_{4} \mathrm{SO}_{4}\right)$ can be used to bind some of the hard water minerals and also may help the herbicide to enter the plant. Urea-ammonium nitrate, organic acids and commercial products containing combinations of these and other ingredients can also help counteract the effects of hard water. Spray solution $\mathrm{pH}$ can also affect herbicide breakdown and subsequent activity. Read the label of any herbicide you intend to use for information on potential water quality effects and measures to optimize efficacy.

Adjuvants-Again, read the label and if an adjuvant is called for, use the type listed at the recommended concentration. Some adjuvants can increase spray coverage, retention and/or penetration. Not using a required adjuvant, using the wrong adjuvant or using an adjuvant at an incorrect rate can all reduce herbicide efficacy. More is not necessarily better.

Time of application-Apply postemergence herbicides early in the day but after the dew has dried. Herbicide effectiveness is reduced if plants are water stressed-as often occurs late in the afternoon.

Coverage - Thorough coverage is important even with systemic herbicides. Consider using a colorant/dye to aid in visualizing spray coverage during directed applications. However, use dyes that are known to have little or no adverse effects on the herbicide efficacy.

\section{Addition of preemergence herbicides in spray} mix - In one study, the combination of glyphosate + metolachlor improved the uptake of both constituents over that of applying either one alone. Other preemergence herbicides or formulations may not have this effect; however, their inclusion may still be beneficial if they provide residual control of Benghal dayflower coming from seed.

The proper selection and application of preemergence herbicides is essential to controlling established Benghal dayflower populations since this weed is a prolific seeder and will reestablish from seed. Preemergence herbicides must be applied and activated before the weed seeds germinate. Activation is usually by irrigation or rainfall. Usually $1 / 2-3 / 4$ " of rain or irrigation is required and this may be somewhat difficult during the dry season in nurseries that do not have overhead irrigation systems. However, rainfall records in Florida indicate there 
would be adequate daily rainfall events occurring most weeks of the year, even during the dry season. Repeated very light daily rainfall amounts after herbicide application may not be adequate to activate the herbicide to an effective depth in the soil/growing medium and could cause a reduction in weed control. Conversely, very heavy rainfall after herbicide application and before the herbicide is adsorbed to the soil/medium may move the herbicide below the germination zone of some of the Benghal dayflower seeds.

\section{Some Factors Affecting the Efficacy of Preemergence Herbicides:}

Benghal dayflower growth - If the seeds have already germinated, it is too late to use a preemergence herbicide (alone).

Application rate - Read the product label completely and make sure to follow all guidelines. Have a knowledgeable person check your calculations to make sure the correct amount of herbicide is used for each tank size. Using lower than recommended rates (sublethal rates) can result in poor control and increased selection for herbicide resistance.

Application uniformity - Preemergence herbicides form a chemical barrier on the soil/growing medium surface. If the herbicide is not applied uniformly there will be areas where control will be poor or lacking (and areas where too much herbicide will be applied and that could cause crop damage).

Herbicide activation-As mentioned above, preemergence herbicides need to be activated in order to be effective. Although activation can in some cases be done by shallow cultivation, in nurseries it is usually done using water. Mechanical cultivation may disturb crop roots and bring more weed seeds to the soil surface. If cultivation reduces crop vigor, the crop can become less competitive with Benghal dayflower.

Herbicide selection-As information on the efficacy of herbicides for controlling Benghal dayflower becomes available, products that are most efficacious should be utilized. However, products with the same site of action should not be used repeatedly or resistance may develop. Also, using the same herbicide over and over can cause steady shifts in the weed spectrum (since no product controls all weeds) and other, perhaps even worse, weeds may replace Benghal dayflower in the nursery.

Watering - Over-watering may increase leaching of herbicides from the soil/medium surface, enhance conditions promoting microbial breakdown of herbicides and enhance weed seedling survival by reducing water stress. Over-watering should also be avoided due to potential detrimental effects on the crops, nutrient leaching, additional production costs and the wasting of a limited resource.

Application intervals - The period of time during which preemergence herbicides remain effective depends on numerous factors including application rate, soil/medium type, irrigation/rainfall, herbicide breakdown characteristics, microfauna in the the soil $/$ medium, etc. Therefore, scouting for weed control failure should be an integral component of a Benghal dayflower control/eradication program. Scouting can save money by signaling if and when follow-up herbicide applications are necessary.

The most effective herbicide control strategies for Benghal dayflower include using a combination of both postemergence and preemergence herbicides.

\section{Selected references}

Budd, G. D., P. E. L. Thomas, and J. C. S. Allison. 1979. Vegetative regeneration, depth of germination and seed dormancy in Commelina benghalensis L. Rhodesian Journal of Agricultural Research 17:151-153.

Culpepper, A., J. Flanders, A. C. York, and T. M. Webster. 2004. Tropical spiderwort (Commelina benghalensis) control in glyphosate-resistant cotton. Weed Technology 18:432-436.

de Souza Lacerda, A. L. and R. Victoria Filho. 2004. Dose-response curves in weed species with the use of herbicide glyphosate. Bragantia 63:73-79.

Faden, R. B. 1993. The misconstrued and rare species of Commelina (Commelinaceae) in the eastern United States. Annals of the Missouri Botanical Garden 80:208-218. 
Ferrell, J. A., G. E. MacDonald, and B. J. Brecke. 2006. Tropical Spiderwort (Commelina benghalensis L.), Identification and Control. University of Florida, Institute of Food and Agricultural Sciences, Florida Cooperative Extension Service Publication SS-AGR-223:

Maheshwari, P. and J. Maheshwari. 1955. Floral dimorphism in Commelina forskalaei Vahl. and $C$. benghalensis L. Phytomorphology [Delhi] 5:413-422.

Olabiyi, T. I. and G. O. Adesina. 2006. Weed as host of plant parasitic nematodes. Crop Research Hisar 32:512-516.

Prostko, E. P., A. S. Culpepper, T. M. Webster, and J. T. Flanders. 2005. Tropical Spiderwort Identification and Control in Georgia Field Crops. Cooperative Exte nsion Service/University of Georgia College of Agricultural and Environmental Sciences Circular 884.

Steptoe, P. J., W. K. Vencill, and T. L. Grey. 2006. Influence of moisture stress on herbicidal control of an invasive weed, Benghal dayflower (Commelina benghalensis). Journal of Plant Diseases and Protection Special Issue 20:907-914.

Walker, S. R. and J. P. Evenson. 1985a. Biology of Commelina benghalensis L. in south-eastern Queensland. 1. Growth, development and seed production. Weed Research 25:239-244.

Walker, S. R. and J. P. Evenson. 1985b. Biology of Commelina benghalensis L. in south-eastern Queensland. 2. Seed dormancy, germination and emergence. Weed Research 25:245-250. 
Table 2. Site-of-action groups, common names (active ingredients), trade names, manufacturers/distributors and contact/systemic activity indication for some postemergence nonselective herbicides with both potential to help control Benghal dayflower and labeling for use around ornamental crops.

\begin{tabular}{|c|c|c|c|c|}
\hline $\begin{array}{l}\text { Common name(s)/ } \\
\text { active ingredient(s) }\end{array}$ & Trade name(s) & $\begin{array}{l}\text { Manufacturer(s) or } \\
\text { distributor(s) }\end{array}$ & Contact & Systemic \\
\hline GROUP & 4 & HERBICIDES & & \\
\hline bentazon & Basagran $^{\circledR} \mathrm{T} / \mathrm{O}$ 1EC & BASF & $\mathrm{X}$ & \\
\hline GROUP & 9 & HERBICIDE & & \\
\hline glyphosate§ & $\begin{array}{l}\text { FireBall 1.55L; Glyphosate 4L; } \\
\text { Glyphosate T\&O 4L; Prosecutor 4EC; } \\
\text { Rattler }^{\circledR} 4 \mathrm{~L} ; \text { Razor }^{\circledR} \text { 4L; Roundup Pro } \\
\text { 4L, 5L; Touchdown }\end{array}$ & $\begin{array}{l}\text { Helena; FarmSaver.com; } \\
\text { Quali-Pro; Lesco; Helena; } \\
\text { Nufarm; Monsanto; Syngenta; } \\
\text { etc. }\end{array}$ & & $\mathrm{x}$ \\
\hline GROUP & 10 & HERBICIDES & & \\
\hline glufosinate & Finale $^{\circledR}$ 1EC & Bayer Environmental Science & $\mathrm{X}$ & \\
\hline GROUP & 14 & HERBICIDES & & \\
\hline flumioxazin & SureGuard ${ }^{\mathrm{TM}}$ 51WDG & Valent USA & $\mathrm{X}$ & \\
\hline oxadiazon & Ronstar $^{(} 50 \mathrm{WSP}$ & Bayer CropScience, Regal & $\mathrm{X}$ & \\
\hline oxyfluorfen & $\begin{array}{l}\text { Galigan }^{\circledR} 2 \mathrm{EC} ; \mathrm{Goal}^{\circledR} 1.6 \mathrm{E}, 2 \mathrm{EC} ; \text { OxiFlo } \\
\text { 2EC }\end{array}$ & $\begin{array}{l}\text { Makhteshim Agan; Dow } \\
\text { AgroSciences; FarmSaver.com }\end{array}$ & $x$ & \\
\hline pyraflufen-ethyl & Octane $^{\mathrm{TM}} 2 \mathrm{SC}$ & SePRO & $x$ & \\
\hline GROUP & 22 & HERBICIDES & & \\
\hline diquat dibromide & Reward $^{\circledR}$ 2EC; WeedPlex Pro 2EC & Syngenta; Sanco Industries & $\mathrm{X}$ & \\
\hline paraquat dibromide* & $\mathrm{Boa}^{\circledR} 2.5 \mathrm{~L} ;$ Gramoxone Inteon ${ }^{\mathrm{TM}} 2.5 \mathrm{~L}$ & Griffin; Syngenta & $\mathrm{X}$ & \\
\hline GROUP & 27 & HERBICIDE & & \\
\hline $\begin{array}{l}\text { pelargonic \& related fatty } \\
\text { acids }\end{array}$ & Scythe ${ }^{\circledR} 4.2 \mathrm{~L}$ & Mycogen & $x$ & \\
\hline \multicolumn{5}{|c|}{$\begin{array}{l}\text { Combination product with more than one site of action } \\
\text { [site-of-action group number in brackets] }\end{array}$} \\
\hline $\begin{array}{l}\text { glyphosate [9] + } \\
\text { prodiamine [3] }\end{array}$ & ProDeuce $^{\mathrm{TM}}$ & Nufarm Americas & & $x$ \\
\hline
\end{tabular}

† Herbicide groups are based according to primary sites of action (Weed Technology 11:384-393, [1997]) and can be used to select herbicides that have differing sites of action. This information can be used to help select herbicides so as to minimize the potential for the development of herbicide-resistant weeds. $9=$ inhibition of EPSP synthase, $10=$ inhibition of glutamine synthetase, 14 = PPO inhibitors, 22 = photosystem I - electron diversion, 27 = unknown.

$\S$ Many populations of Benghal dayflower are known to be tolerant of glyphosate, especially at lower rates of activity (see - Some factors affecting the efficacy of postemergence herbicides - above).

$\ddagger$ Based on research trials, this active ingredient has activity against Benghal dayflower germinating from seed. Research is underway to determine what other herbicides on this list will also help control Benghal dayflower.

* Restricted use pesticide. 